\title{
BOTANIC GARDEN PROFILE \\ THE DEVELOPMENT OF THE NEW UNIVERSITY \\ OF BRISTOL BOTANIC GARDEN
}

Nicholas Wray ${ }^{1}$ MHort.(RHS), FIHort

\begin{abstract}
In 2002 the decision was made to move the University of Bristol Botanic Garden (UBBG) from its then current location. This move would be the third in the Garden's history. The four core collections for the new garden were selected in line with modern international policies on botanic garden management, recent research and the University of Bristol's teaching needs. The themes of these collections are evolution, rare and threatened native and local flora, useful plants and Mediterranean-type flora. This paper describes the development of the plant collection policy, the vision and concept for the new garden, together with a detailed explanation of the work to relocate the existing plant collections, and the design and establishment of the new garden.
\end{abstract}

\section{HISTORY AND BACKGROUND}

The original University Botanic Garden in Bristol was founded by Adolph Leipner in 1882. A lecturer in German, Botany and Zoology, he persuaded his employer that they should invest in a teaching garden that would be known as the 'Botanic Garden'. They agreed and provided an initial grant of $£ 15$, and by raising additional funds of $£ 8915 \mathrm{~s}$. $41 / 2 \mathrm{~d}$., he was able to plant up the garden with 509 plants and purchase 247 packets of seeds (Delany and Winn, 2002). Further fundraising allowed for the construction of glasshouses and a small laboratory. By the time University College, as it was then known, obtained its royal charter in 1909 and became the University of Bristol, the original botanic garden, now known as the Leipner Garden, was well established.

The Garden was much used and enjoyed by its students and soon outgrew the available space, forcing the establishment of a second garden known as the Field Garden adjacent to the Leipner Garden. In 1908 the University received a gift of $£ 100,000$ from tobacco magnet Henry Overton Wills III, part of which was to be used for the construction of botany and zoology laboratories. These were sited on the Leipner Garden whose focus would move to the much larger Field Garden. In the 1920s the Field Garden flourished under the patronage of Hiatt Baker who became Pro-Chancellor of the University in 1929. The Garden contained order beds, a conifer collection and many fine trees. New laboratories were built and student numbers increased. Hiatt Baker died in 1934. In 1939 the University commissioned a commemorative stone planter in memory of his life and work. This was sited in the heart of the Garden which, from

${ }^{1}$ Nicholas Wray is Curator at the University of Bristol Botanic Garden.

Address: University of Bristol Botanic Garden, Hollybush Lane, Stoke Bishop, Bristol, BS9 1JB.

E-mail: nicholas.wray@bristol.ac.uk 
1938, had officially become known as the Hiatt Baker Botanic Garden. In the 1950s the expanding University needed purpose-built administration offices to run its affairs. It was decided to locate these on the Hiatt Baker Botanic Garden site and to relocate the Garden to Bracken Hill, a new site 1.5 miles from the central University and near the Clifton Suspension Bridge, which had been gifted to the University in 1949 by Melville Wills, son of Henry Overton Wills III. In 1959 the plant collections were lifted and moved to the two hectare Bracken Hill site which contained a large Victorian family house, associated stable buildings surrounded by a fine Pulham's rock garden, formal Italianate pool and kitchen garden, small copse, many fine trees, shrubs and glasshouses. The house was used as a student hall of residence. The former Victorian garden was gradually replanted over forty years to form a diverse teaching and conservation collection of plants, with rare and threatened local native plants, New Zealand, South African, medicinal and economic plants as its core collections. In 1975 an Association of Friends was formed to support the Garden and provide a vehicle for fundraising to help meet the increasing costs of developing and running it. An adult education programme was developed with a range of courses including the Royal Horticultural Society's Level 2 Horticulture course. Schools visited and many diverse events, including very popular plant sales, were organised that encouraged many thousands of people to visit the Garden every year. A long association of opening the Garden for the National Garden Scheme commenced in 1978 and continues today.

In 2000 as part of a University estate-wide property review, a report found that refurbishment of the main house as a hall of residence would be too costly and recommended the sale of the house. This threw the spotlight onto the future of the Botanic Garden. A separate Botanic Garden Steering Group chaired by Professor Sir John Beringer was set up in January 2002 to investigate and consider the options for the Botanic Garden. After considerable work and wide consultation with all user groups, it was decided that the favoured option was to relocate the Garden to The Holmes, located in the heart of the Stoke Bishop student residential community. It was felt that by moving the Garden closer to the main student population, links and increased usage could be made of it as an educational and amenity resource (Figs. 1 and 2). In addition, by moving to The Holmes, the Garden would share the resources of office space, machinery and support facilities operated by the University Gardens and Grounds Department, thus creating a financial saving.

\section{THE HOLMES}

Constructed in 1879 by William George, the main house at The Holmes (Fig. 3) is set in 1.77 hectares of gardens near to the western edge of Durdham Down. The house, which is constructed of local pennant sandstone, was gifted to the University in 1943. Prior to its construction the land formed part of extensive Elizabethan parkland owned by the Cann family, whose home, Stoke House, built in 1669, is located $200 \mathrm{~m}$ to the west, (Abbott, 1979). It is thought that the stone for Stoke House originated from The 


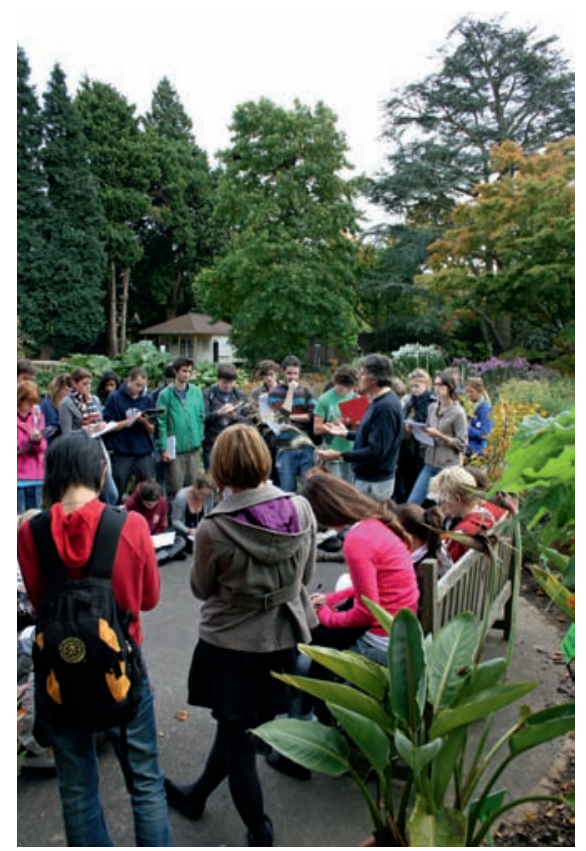

Fig. 1 Biology undergraduates use the garden as part of their formal studies. Photo: Andrew Winfield.

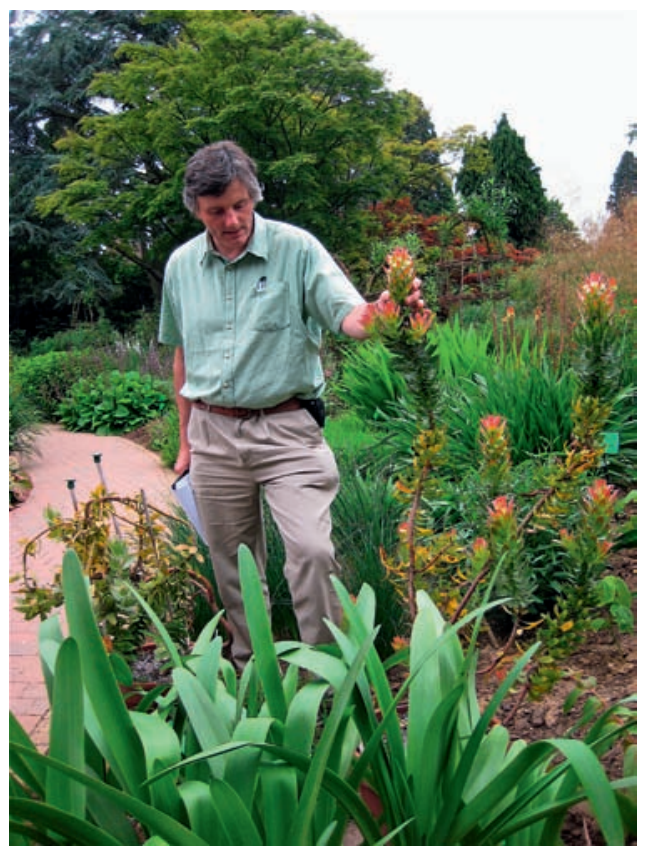

Fig. 2 Curator, Nicholas Wray, leading a tour as part of the UBBG adult education programme. Photo: Judy Green.

Holmes and created the dell. Ancient English oaks, including one of 400 years and, until 2004, a sessile oak of 600 years, grow in one corner of the garden. With a long history of human settlement and elements of ancient pasture and woodland, The Holmes needed careful consideration when planning the new botanic garden. A Historic Landscape Survey Report (Lear, 2003), an Ecology Report (Wessex Ecological, 2003) and an Archaeological Survey (Hicks, 2003) were commissioned to assess the site and provide relevant information as part of the planning application to establish a botanic garden. The garden has many fine trees including two large Cedrus atlantica Glauca Group, a number of Taxus baccata, Catalpa bignonioides and an Idesia polycarpa. With support from the City Tree Officer team many of the trees of poor shape, unsafe condition and low or non-relevant botanical interest were removed to allow more light into the garden and provide the opportunity for the establishment of a new tree population meeting the needs of the University of Bristol Botanic Garden (UBBG).

\section{SITE CHARACTER}

The Holmes is situated between $80 \mathrm{~m}$ and $90 \mathrm{~m}$ above sea level on a gently undulating site. To the south a paddock area faces due south and has been developed with a $604 \mathrm{~m}^{2}$ glasshouse containing five different temperature zones. To the north the site 


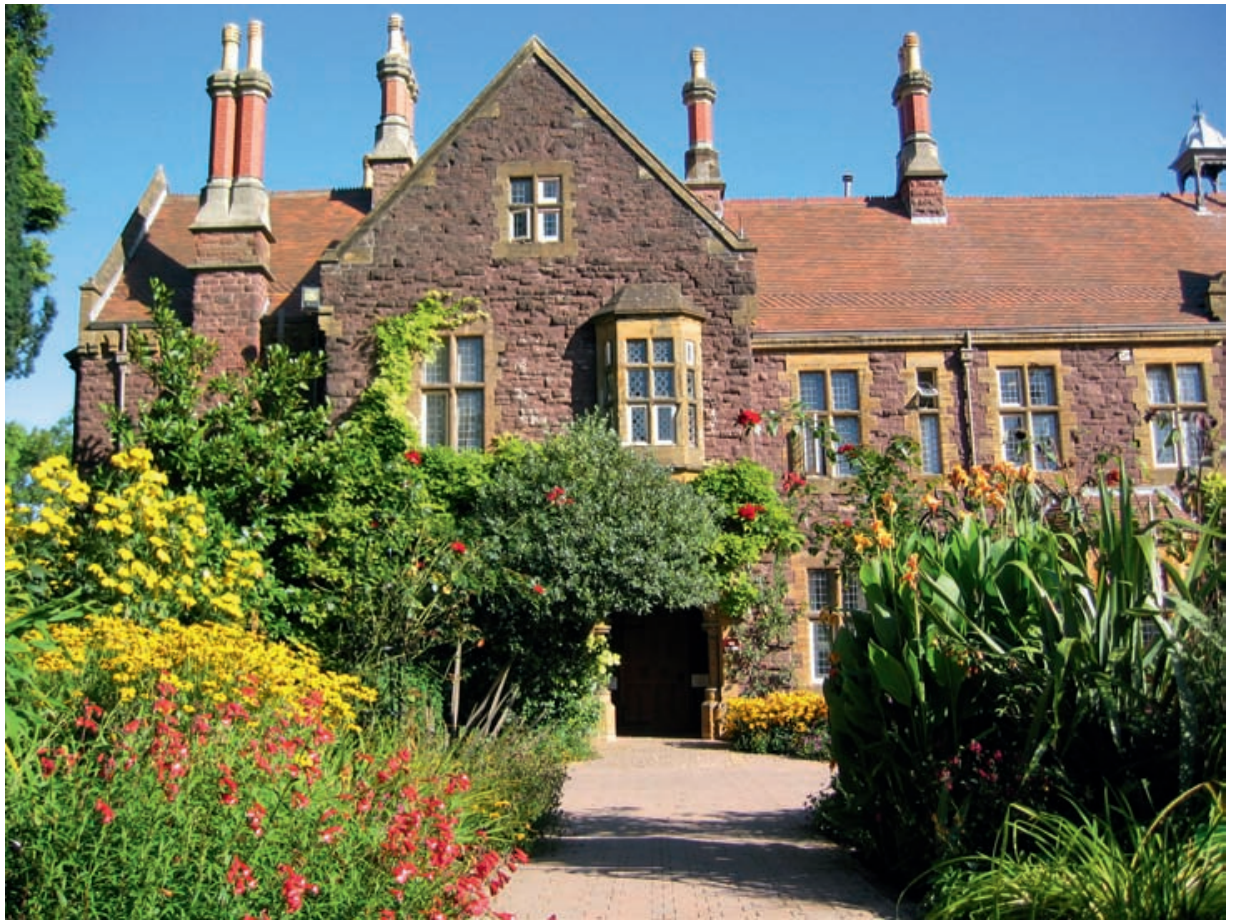

Fig. 3 The Holmes, built in 1879 as a family home, is now an undergraduate hall of residence and conference facility. The Botanic Garden has been created around this fine Victorian building. Photo: Nicholas Wray.

falls away giving a north west facing slope. This has been developed as the site of the Chinese Medicinal Herb Garden. The Holmes straddles the transition zone between two very different geological formations. From the dell northwards is Devonian Old Red Sandstone (370 million years old), while underlying the majority of the garden to the south is lower Carboniferous limestone (350 million years old). Both are hard and slow to weather, have been titled and uplifted and now form the high ground across this part of Bristol. Both rock types influence the soil which is a silty clay and slightly alkaline overlying the limestone and neutral to slightly acidic overlying the Old Red Sandstone. The presence of Quercus petraea indicates the slightly acidic nature of the soil towards the north of the site. The UBBG is situated in a leafy suburb of Bristol known as Stoke Bishop. Many fine ornamental trees adorn the streets and gardens. This mature tree cover provides considerable shelter from the prevailing south westerly winds.

\section{DEVELOPING A VISION FOR THE UBBG}

Early on in the discussions about the future of the UBBG it was identified that the primary role of the Garden should be to support teaching and research within the University. Additionally, it was recognised that the Garden had an important role to play 
with its adult education programme and that links with schools and local community groups should be developed further. Within the local community the Garden should be developed as a cultural resource for the citizens of the city.

A key aspect to the role of the UBBG would be the uniqueness of its plant collections, particularly the Evolution and the Rare and Threatened Native Plant Collections, to the Bristol area. Evolution would be the defining theme that would run through the whole garden. It would be a strong educational message that the Garden would make in its educational programmes and interpretation. The Rare and Threatened Native Plant Collection would be used as a conservation resource. This was seen as a crucial role that would help support the Garden's efforts towards the Global Strategy for Plant Conservation (GSPC) (Secretariat of the Convention on Biological Diversity, 2002).

To underpin the Garden's work the mission statement was revised to reflect the Garden's focused aims and a motto was developed:

\section{Our Mission}

To provide a diverse, correctly named, well labelled and attractively displayed teaching and conservation collection of plants in support of the University of Bristol's teaching and research endeavour and its educational commitments to the wider community.

\section{Motto}

To educate, communicate and conserve.

This clear vision and mission statement would guide the development of the UBBG.

THE MAIN INFLUENCES ON THE CONCEPT FOR THE UBBG

Three important factors have shaped the physical character and plant content of the UBBG:

1. The publication of the Angiosperm Phylogeny Group (APG) (APG II, 2003) research into the relationships between flowering plant families derived from the sequencing of DNA contained within their genes.

2. In 2002 the GSPC was developed by the world's botanic garden community and adopted by the Conference of the Parties of the Convention on Biological Diversity (CBD).

3. The comprehensive collection of plants numbering around 4,500 species that had been assimilated since the Garden's foundation in 1882.

These three points would have a profound effect on the design of the new Garden, shape its appearance and build a new Garden with a strong and unique character. Details of how they would do this are listed below: 
1. At an early stage in the discussions surrounding the concept of the Garden, Garden Director, Professor Simon Hiscock was keen to showcase the work of the APG in a large purpose-built display occupying the centre of the new site. This would be the first time a UK botanic garden would showcase this important research in an actual planted display. Support for this area came through a research connection with the Royal Botanic Gardens, Kew (RBG Kew). Professor Peter Crane, then Director of RBG Kew, agreed to become special botanical advisor. For a period of eighteen months from 2003-2005 Professor Crane made frequent visits advising on the design of the Angiosperm Phylogeny display and contributing to the discussions regarding the design of the garden. An investigation of the Garden's existing plant collection in comparison with published research (Judd et al., 2002) provided the plants for the design comprising a branching network of gently curving paths leading the visitor from a large raised pool, home to one of the earliest angiosperm families, the Nymphaeaceae. From here, plantings would radiate out along borders with diverse displays of Monocots, Basal Eudicots and Eudicots. The display would be the centrepiece to the new Garden (Fig. 4). The final design was generous, allowing the cultivation of some 450 different species illustrating the evolution of flowering plants from common ancestry to the diversity of forms known today.

2. The GSPC, with its 16 distinct targets, has provided a clear point of reference during the initial concept and later design phase of the UBBG. In particular, Target 14 , which highlights the need to promote public understanding and education of the importance of plants, and Target 8 , which highlights the need to have $60 \%$ of native plants in viable ex situ collections by 2010 , have been carefully considered in the design. The University Botanic Garden has always had a prominent local native plant display. This policy was developed further by incorporating recommendations laid down in the GSPC to showcase our rare and threatened local flora.

3. The plant collections which formed the Bracken Hill Botanic Garden were reviewed in 2003. With pressure to justify the resources needed to support the new Garden, the existing plant collections were reorganised into four concise core collections. Each would be distinct and have a dedicated role in teaching, education and conservation and would accommodate the best and most relevant of the plant collections established at the old garden at Bracken Hill. The four themed core collections are:

i. The Plant Evolution Collection, incorporating the New Zealand and South African plant collections

ii. Plants of Mediterranean Climatic Regions, incorporating the European, Western Cape of South Africa, Southern and Western Australia, Central and Northern Chile and Western Californian plant collections

iii. The Rare and Threatened Native Local Plants Collection, incorporating the native flora of the Bristol area and South West Peninsula

iv. The Useful Plants Collection, incorporating the European and Chinese medicinal plants and the Economic Plant Collection 

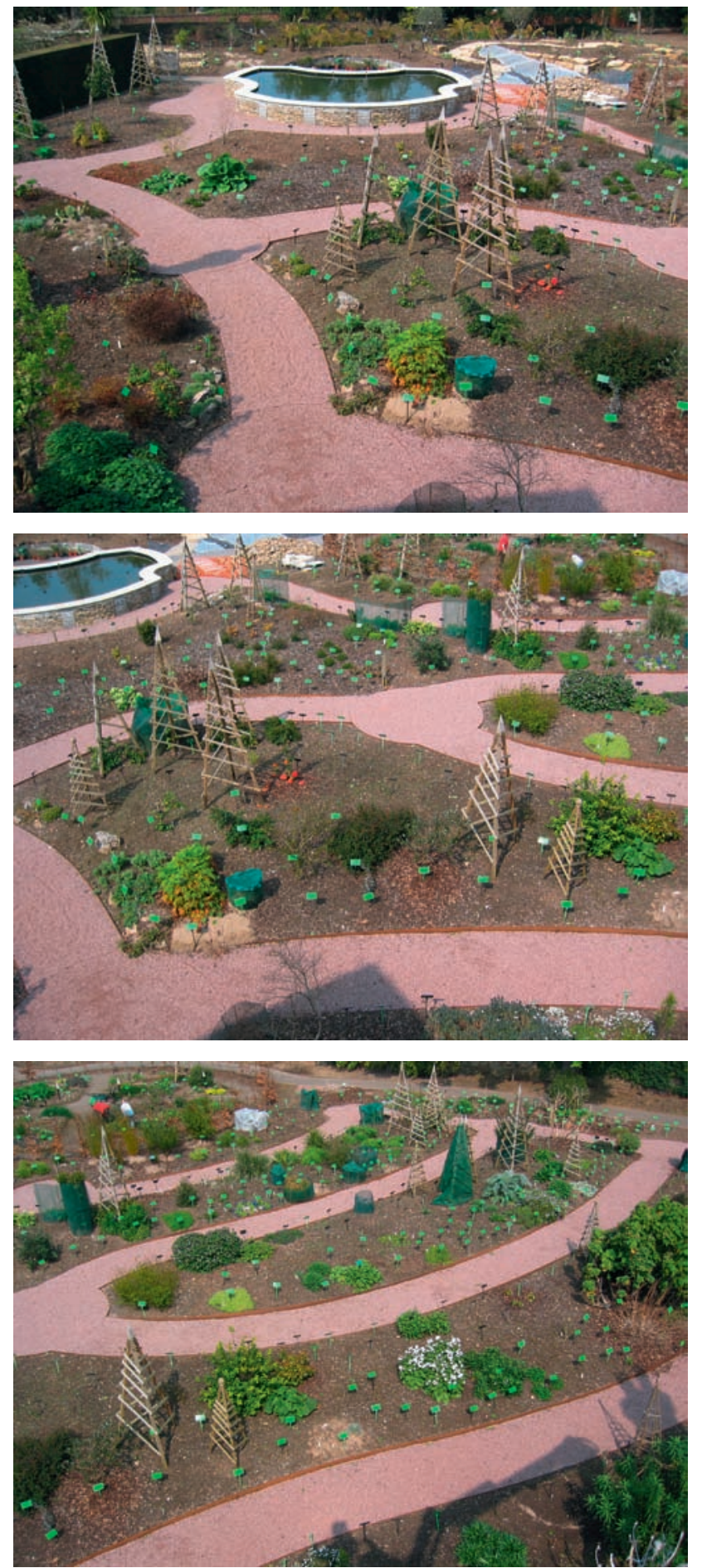

Fig. 4 The Angiosperm

Phylogeny Display is the first display to be built and planted in the United Kingdom that represents the APG II (2003) research. It is located in the centre of the new garden and starts with a raised pool, home to one of the earliest angiosperm families, the Nymphaeaceae. Photos: Nicholas Wray. 
These carefully chosen core collections would fulfil the teaching, research and conservation requirements of a small university botanic garden in the 21 st century.

\section{RELOCATION}

Having established the core collections policy, the propagation work which had commenced a year earlier in 2002 was expanded. It was clear from the outset that if the UBBG was to be a success the majority of the existing plant collections would need to be propagated. The time available to carry out this role, coupled with the scale of the number and diversity of plant material, represented a huge challenge. At the start of the propagation process attention was focused on difficult subjects and those with little material. If failure occurred this would allow time to return to the parent plants and try again. This considered approach to propagation allowed new plants of woody subjects to be raised without having to resort to the extreme measure of lifting mature plants. Some plants continued to prove difficult and a short-list of these was made. For example, Diospyros kaki (Persimmon) and Moltkia petraea were two plants known from previous experience to be difficult to propagate. Earlier attempts to vegetatively propagate these had yielded no success and so attempts at cutting and layering at different times of the year were tried. Semi-ripe cutting material from July to September eventually proved to be the most successful for the Moltkia and root cuttings for the Diospyros. IBA rooting hormone liquid was used routinely on a wide range of species, always ensuring that the hormone was well within its use-by date and had been appropriately stored. Some of the plant stock was slow to root, in some instances taking six to nine months. This extended period raised the risk of fungal infection. To combat this, propagation facilities were kept very clean and cutting material was routinely drenched with Aliette $80 \mathrm{WG}$ containing fostyl-aluminium 80\% w/w and Croptex Fungex containing 95g/1 80\% w/w cupric copper as copper ammonium carbonate to keep infection to a minimum.

The Evolution Core Collection, home to the New Zealand and South African plant collections, was one of the first collections to undergo wholesale propagation. With a shortage of time available propagation techniques were tried that would not normally be usual practice. With some plants yielding no seed, or at least no viable seed, reliance on vegetative means was the main method by which the collections were propagated. With the use of a wet leaf mist bench, wet and dry heated propagation cases, extensive cold frame space and a cool polytunnel, the propagation gathered pace. At all times between autumn 2001 and spring 2005 propagation space within the nursery was used to full capacity. Over this four year period of time thousands of new plants were produced. Each summer and autumn an additional concerted effort to collect seed provided a fallback position if vegetative methods failed.

In autumn 2004 it became clear that the plants would have to be relocated by 31 October 2005. The news of a final move date provided the stimulus for a change in the propagation programme away from cuttings of woody plants. Time would now be spent lifting herbaceous and bulb collections through the dormant season. These would be 
transported to the new garden from March 2005 through the summer, leaving September and October to transfer the glasshouse collections. To coincide with the dormant season the wholesale lifting of plants commenced in November 2004. This work continued uninterrupted until May 2005. During this period the audit of the plant collections which had commenced early in 2004 gathered pace. This important work captured all the plants growing in the garden: their location, accession details, health condition and number were recorded on an audit information sheet. This information was entered into a database built for the audit which allowed the core collection destination to be added. In 2009 this information was migrated to a purpose-built botanic garden database provided by Iris Botanical Garden Database Systems.

It became clear that the core team of five horticultural staff supported by twelve volunteer gardeners would not be able to complete the workload in the available time. In the autumn of 2004 a request for help was launched in the Friends of the Garden newsletter. Within one month the number of volunteer gardeners had risen to 21 . A reorganisation of duties allowed the core team of staff to concentrate on propagation, watering and auditing of the collections, whilst the enlarged team of volunteers carried out all the weeding and maintenance in the garden, weeding, feeding and pruning within the nursery and supporting staff with the lifting, auditing, record-keeping and administration. As the lifting of herbaceous plants greatly increased, the need for pots and appropriate compost and the commensurate increase in costs could not be sustained. The need to pot up the herbaceous collections, as opposed to just lifting and storing them, became a priority. The new garden at The Holmes required complete reorganisation. This would take years to achieve and during this period lifted plants would have to survive until their new homes were prepared. What was needed was a compost that would not degenerate in the short term and would be suitable for a wide range of plants, and a container for each plant that was cheap, durable and easy to move. A labelling system that was clear and failsafe so that no accession information would be lost or corrupted was also required.

After initial experiments, a 25\% peat, $75 \%$ medium-grade bark mix, along with an 18-month life, slow-release fertiliser (Osmocote), developed a 'general mix'. This provided an open structure for root growth, good moisture retention qualities and lightness, an important factor for staff and volunteer well-being during the move. The lifted plants were 'bagged' into thick grade white plastic sacks. Each sack had holes pierced into the bottom with a garden fork and the sides rolled down to form a 'ruff'. This allowed the entry of air and light without plants getting 'lost' in their bag, whilst the 'ruff' made it easier for each bag to be picked up and moved without damaging the plant. The white colour was chosen so that the bags would not warm up too early in spring, promoting unwanted early growth. In summer the white colour would reflect light and prevent root zone overheating and plant stress which would inevitably have occurred if traditional black sacks were used. This proved important as 2005 and 2006 were both long, hot, dry summers. Each plant had a white plastic nursery label written in pencil pushed deep into the compost and a plastic bed label written in waterproof pen 
pushed into the bag. The name, accession number, number of plants lifted and location within the garden at Bracken Hill was recorded on each label. The information was then logged on a lifting form devised to keep track of stock numbers and movement. The dual-labelling system would prove invaluable in ensuring that no plant became separated from its accession information. The 'bag system' enabled one person to pick up a bag in each hand, something that would not be possible with the equivalent sized pots. Bags could be easily slid into the back of the vans used for the move to the new site. These small points made a huge difference to the time and motion of the moving process and the long-term care of lifted plants. They enabled the small team to relocate over 12,000 plants safely and conveniently in a relatively short seven month period of time.

Between April and October 2005 the lifted and propagated plants which had been corralled into temporary standing grounds were moved to the new garden. To keep order and avoid 'lost time' in looking for lifted plants, stock was moved and positioned on the new site according to which bed and display it originated from in the old garden. Staff had detailed, intimate knowledge of individual plant locations. This resource of knowledge would be important to help keep track of things while the UBBG was in a state of fluidity and until the plant displays were designed. It would be from these carefully laid out temporary standing grounds that plants would be easily selected to form the new plant displays.

\section{FROM CORE COLLECTIONS TO CONCEPT DESIGN}

In January 2003 work started on a six month process of surveying, recording, drawing up specifications and understanding the feel of the new UBBG site so that initial concepts on how the plant collections would be displayed could begin to take shape. Through frequent site visits from the Garden Director, Professor Simon Hiscock and Curator, Mr Nicholas Wray, a plan started to formulate of where the plant collections would be displayed and how they would interrelate with one another. It was considered particularly important to capitalise on the microclimatological opportunities that The Holmes garden presented. These included a long sheltered west-facing stone wall, a sunken dell, a south-facing paddock and a north-facing wooded slope. A change of geology and soil $\mathrm{pH}$ was also noted and numerous inspection pits were dug to examine soil profiles. With all this detailed information, a clear idea of where the collections would be sited emerged. Also, a written design brief incorporating the University's requirements from the Garden was prepared. Bringing all this together into a design would require the work of a creative, sympathetic and understanding landscape architect. Fortunately Land Use Consultants were successfully appointed. Assigned to the project was Land Use Consultant Principal Adrian Wikely, whose intuitive approach immediately recognised the key elements of the site, our requirements from the plant collections and our ideas for the site. One clear challenge would be solving the mixed use of student and visitor pedestrian traffic, along with vehicle access and parking. Through a two week intensive site investigation and design process three concept designs were produced. Two were 
exploratory, but the third fitted comfortably with our brief, satisfied the ergonomic demands of the site and the needs and inter-relationship of the plant collections and how we wanted them to be used. It was this design that was adopted. A key element was disabled access. This was achieved by an organic flowing network of paths built to the latest Disability Discrimination Act (DDA) standards that leads visitors through all the main plant displays and allows the garden to reveal itself slowly thereby increasing is perceived size, (Leadlay \& Greene, 1998).

\section{THE CONCEPT DESIGN AND CORE COLLECTIONS}

Integrating the core collections into inspirational and educational displays has been a careful and thoughtful process. The design process started with dialogue and site visits between the Garden Director and Curator. The Curator then produced the detailed design plans maximising the use of the existing plant material and augmenting it with new material where necessary. Issues such as plant cultivation, maintenance, labelling and future interpretation, together with long-term management of the collections, was carefully considered in the design. The designs were then presented to, and discussed with, the Curators Advisory Group (made up of University stake holders, outside advisors and chaired by the Garden Director). Any suggested amendments were then added and the design was then signed off for implementation. Work was planned carefully as many individual projects had to run simultaneously. A week by week planning system was developed which took into consideration seasonal and routine maintenance and events which take staff and volunteer time away from new projects.

\section{CORE COLLECTIONS AND THEIR REPRESENTATION IN THE UBBG}

The Evolution Collection consists of a walk through a sunken dell charting the evolution of plants on land, from green algae to flowering plants. This evolutionary walk takes the form of a journey through geological time from the 500 million year-old Cambrian period to the Cretaceous period, 145 to 65 million years ago, using appropriately chosen rocks and fossils to reflect the passage of geological time. Living representatives from various groups of modern land plants appear along the walk within the geological time zones in which they first evolved. These include mosses, ferns, and club mosses from the Devonian, conifers and cycads from the Permian and flowering plants from the late Jurassic and Cretaceous periods. Of note are a group of young Araucaria araucana and Wollemia nobilis around which grow Cycas revoluta and many fern species (Fig. 5). The dell climaxes with an explosion of flowering plants including a beautiful display of magnolias.

The Angiosperm Phylogeny Display has been designed to illustrate our modern understanding of the evolutionary relationships between flowering plant families based on the sequencing of the DNA contained within their genes, (APG II, 2003). The constant branching family tree (phylogeny) leads you through a diverse plant display 


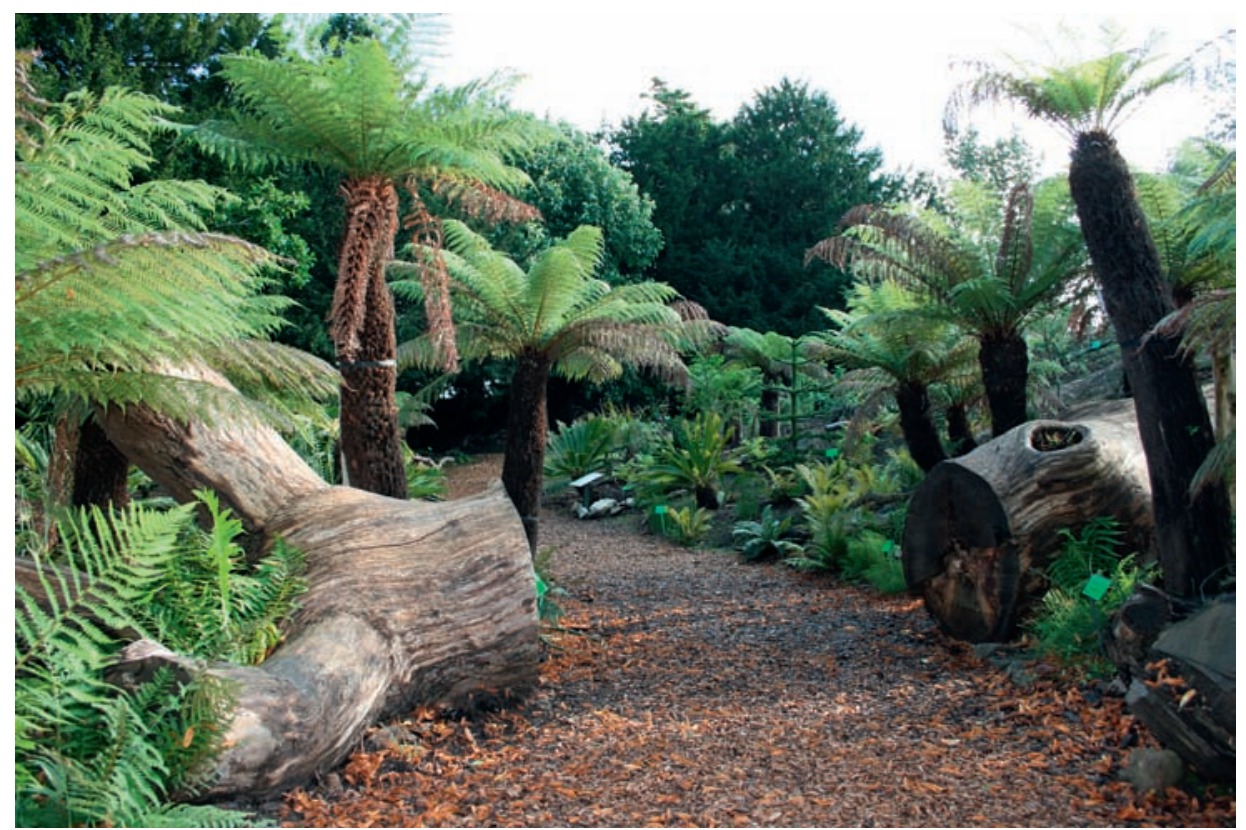

Fig. 5 The Evolution of Land Plants Display is home to luxuriant soft tree ferns, Dicksonia antarctica, which grow around a fallen oak tree used as a sculptural representation of the climax size of giant clubmosses that once grew in the Carboniferous period 290-354 million years ago. Photo: Nicholas Wray.

from the most primitive 'basal angiosperms' from which all other lineages of flowering plants have evolved. Common, unusual and exotic species are grown in a large display that now places close ancestors with one another in surprising juxtapositions, like the tropical semi-aquatic lotus, Nelumbo nucifera alongside its close cousin the London Plane tree, Platanus $\times$ hispanica. The display starts with a raised lily pool which is home to a collection of species water lilies. In summer these are joined by more tender relatives such as Euryale ferox and Victoria cruziana.

The Mediterranean Climate Regions Collection consists of plants from the five mediterranean climate regions: the Mediterranean Basin of Europe and North Africa, Western California, Northern and Central Chile, Western and Southern Australia and the Western Cape of South Africa. Within each geographic region plants are arranged in their natural habitats and illustrate their adaptation to a seasonally dry environment often prone to fire. The display occupies the most sheltered part of the garden along a $90 \mathrm{~m}$ west-facing wall and $60 \mathrm{~m}$ south-facing embankment that has been built to an angle of $20^{\circ}$ to catch the winter sun. Plants have been chosen to illustrate convergent evolution (Fig. 6).

The European Mediterranean Zone display is arranged in different habitats: steppe, garigue (Fig. 7), maquis and climax forest. In the centre is a small section devoted to Mediterranean agriculture and shows some of the plants that have been domesticated by man. 


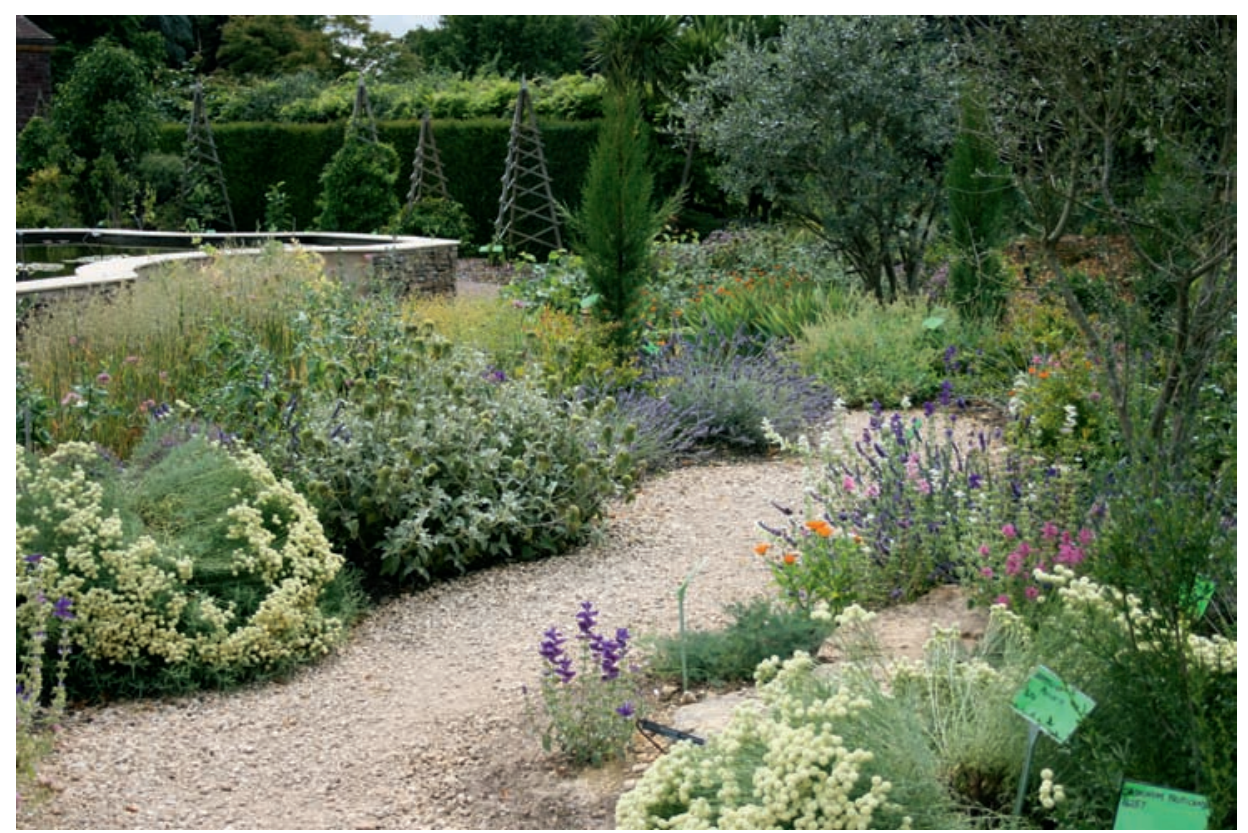

Fig. 6 The European Mediterranean Zone Collection contains plants from evergreen forest, garigue, maquis, and steppe habitats. One area is devoted to Mediterranean agriculture, where a number of familiar crops are grown including olive, pomegranate, durum wheat, vines, carob, garlic, figs and pistachio. Photo: Nicholas Wray.

The Western Cape of South Africa section is home to an extensive collection of wild collected plants (Figs. 8 and 9), particularly those from the fynbos biome, including species from the Proteaceae, Ericaceae and Restionaceae families, many of which have unique pollination systems. Part of the display is represented outside with the more delicate examples including a large collection of bulbous plants and pelargoniums grown in the warm temperate zone of the glasshouse. The display has been augmented through plant collecting expeditions carried out by the Curator $(1999,2000, \& 2001)$ in collaboration with our partnership garden in South Africa, The Garden Route Botanic Garden (Garden Route Botanic Garden, 2006). The Western and Southern Australian, Northern and Central Chile and Western California displays are currently being planned. When complete, the display will allow visitors to walk around virtually half the garden without leaving the Mediterranean climate zone.

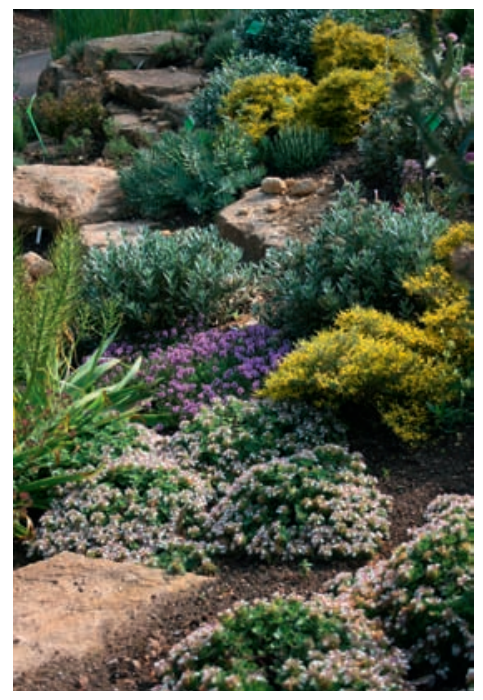

Fig. 7 Convolvulus cneorum, Anthyllis hermanniae, Teucrium pyrenaicum, Scilla peruviana and Euphorbia rigida are plant species grown in the garigue habitat of the European Mediterranean Zone Collection. Photo: Nicholas Wray. 


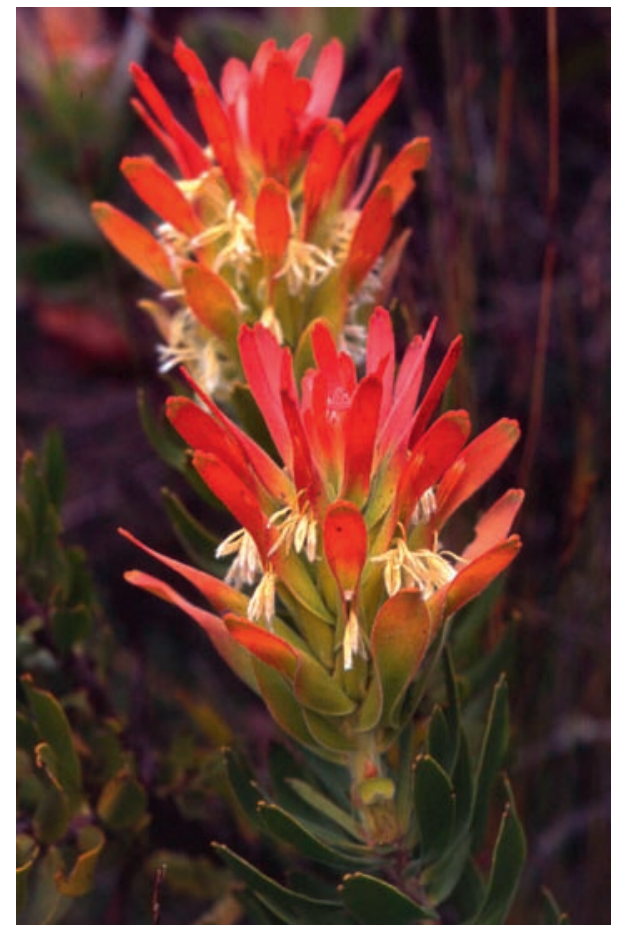

Fig. 8 Wild collected plants of the sunbird- and sugarbird-pollinated Red-crested Pagoda, Mimetes cucullatus flourish in the fynbos biome of the Western Cape of South Africa Mediterranean Climatic Regions Collection. Photo: Nicholas Wray.

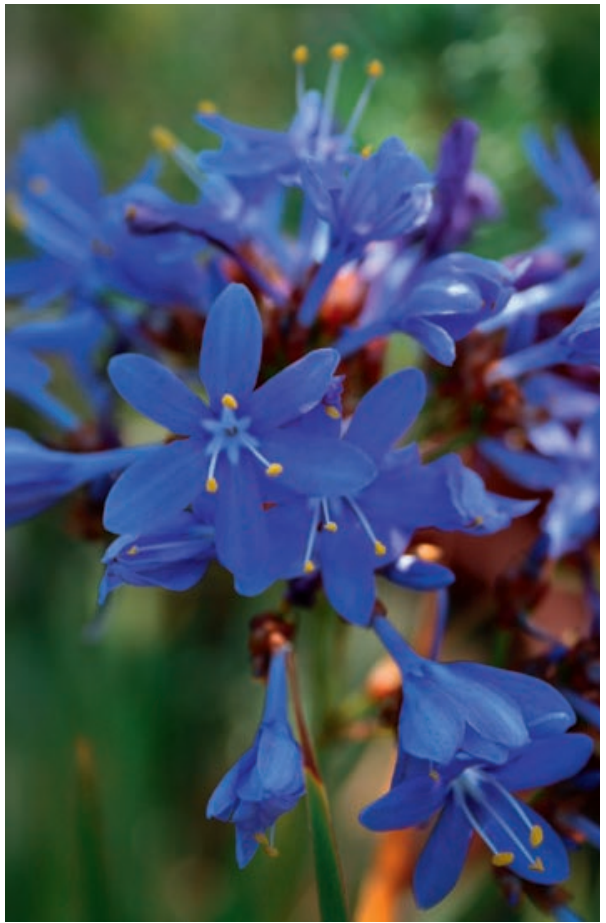

Fig. 9 Nivenia binata is a sub-alpine species from the fynbos biome. Rare in cultivation, it forms part of the Western Cape of South Africa Mediterranean Climatic Regions Collection. Photo: Nicholas Wray.

The Useful Plants Collection integrates the Chinese Medicinal Herb Collection, European Herb Collection and Economic Plant Collections. These three collections were first developed at Bracken Hill. The Chinese Medicinal Plant Collection was developed from 1998 onwards as a partnership between the University Botanic Garden and the Register of Chinese Herbal Medicine. The move to The Holmes has given the opportunity for a new and much larger Chinese Herb Garden to be built in the shadow of a large female Ginkgo tree. The Garden became partnered with the Nanjing Botanical Gardens in China in 2008. This is the first comprehensive teaching garden of Chinese medicinal plants in Europe that serves three broad aims; education, research, and conservation. The Garden has a series of themed displays and, most importantly, a series of 'use categories' displays plants according to how they are used medicinally. The Garden also contains conservation and research displays, an ornamental display associated with medicinal herb gardens, a peony display and a 'laing' over which climbing plants are grown and under which visitors can walk (Fig. 10).

The European Herb Collection has been laid out in a circular form similar to the early physic garden at Padua in Italy which is often thought of as the birthplace of 
the modern botanic garden. The new herb garden has been planted to illustrate twelve use categories that illustrate various parts of the body and the plants that may be used to treat them. The garden contains both European and some North American plants that have long been cultivated in Europe.

The Economic Plants Collection contains an extensive collection of tropical crop plants, such as coffee, cocoa, cinnamon, sugar cane and many medicinal plants such as Catharanthus roseus (Madagascan periwinkle). In time the display will be expanded to contain all the major cereal crops from around the world together with their wild ancestors and early cultivars developed by man.

The Rare Local Flora and Threatened Native Plant Collection has been greatly expanded within the UBBG in line with modern botanic garden policies, (Wyse-Jackson \& Sutherland, 2000) and (Cheney et al., 2000) with the development

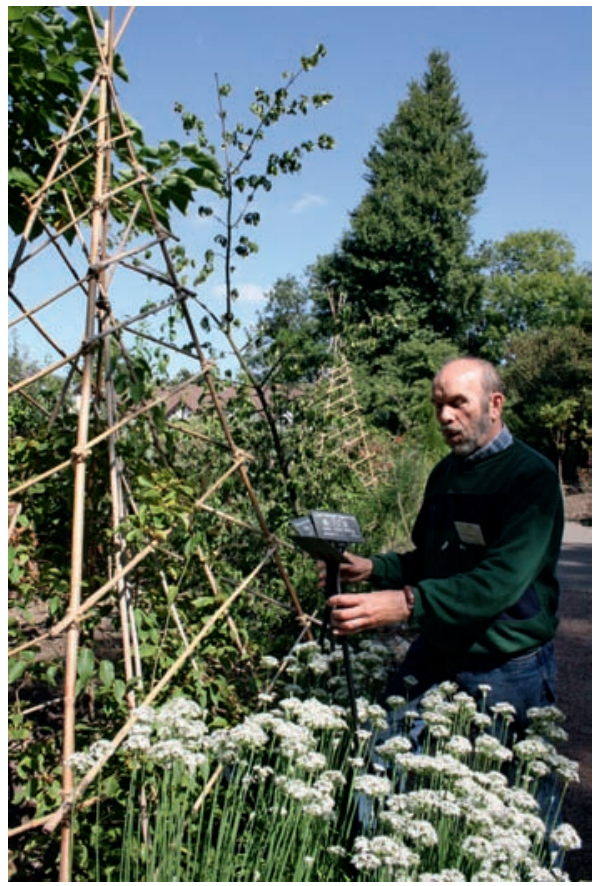

Fig. 10 The Chinese Medicinal Herb Garden, part of the Useful Plants Collection, is divided into 'use categories' according to how the plants are used to treat the body. Photo: Nicholas Wray. of seven interconnecting habitats that occur locally in the Bristol and West Country area. These are located prominently near to the garden entrance and are home to many nationally scarce and threatened plants and some locally endemic species.

The seven habitats created, together with examples of some of the key threatened species grown are listed as follows:

1. Calcareous grassland and scrubland overlying Carboniferous limestone, illustrating the flora of the Avon Gorge and Mendip Hills:

Allium sphaerocephalon (Fig. 11, top left), Arabis scabra, Anisantha madritensis, Dianthus gratianopolitanus (Fig. 11, middle left ), Helianthemum apenninum, Sorbus bristoliensis (endemic) (Fig. 11, middle right), S. wilmottiana (endemic), Trinia glauca, Veronica spicata subsp. hybrida (Fig. 11, top right)

2. Calcareous grassland overlying Oolitic limestone, illustrating the flora of the Cotswold hills and river valley systems:

Daphne mezereum, Fritillaria meleagris, Juniperus communis, Pulsatilla vulgaris, Salvia pratensis

3. Seasonally flooded sedge peat meadowland, illustrating the flora of Somerset Levels: Dactylorhiza praetermissa, Myrica gale, Osmunda regalis 
4. Woodland edge, illustrating the local hedgerow and woodland edge flora: Stachys alpina, Ornithogalum pyrenaicum, Lithospermum purpureocaeruleum, Melittis melissophyllum

5. Calcareous and neutral woodland illustrating the flora of Leigh Woods and the Mendip Hills: Carex depauperata, Sorbus anglica, S. eminens, S. porrigentiformis, S. torminalis

6. Coastal cliffs and hills illustrating the grassland flora and the transitional flora between dunes and dune slack to coastal meadows:

Allium ampeloprasum, A. ampeloprasum var. babingtonii, Althaea officinalis, Eryngium campestre, Matthiola sinuata, Rumex rupestris, Scirpoides holoschoenus

7. Lake and pool edge illustrating the aquatic flora of rhynes and ditches:

Menyanthes trifoliata, Ranunculus ophioglossifolius

Of strategic importance is the Avon Gorge, Leigh Woods and Mendip Hills display which has been carefully and sympathetically built using local water-worn Carboniferous limestone reclaimed from the original garden at The Holmes.

Carboniferous limestone pavements were systematically surface quarried from the Mendip Hills, Somerset in late Victorian and Edwardian times. The rock was almost exclusively transported to Bristol to satisfy the fashion for suburban rock gardens and grottos. To better display the individual pieces of rock the existing rock garden was dismantled in May 2008. It was rebuilt ensuring that the rocks with the strongest characteristics were better displayed and that the topography was raised creating a 'mini Avon Gorge' and Mendip Hill area (Fig. 11, bottom left and right).

The primary path network was designed to flow directly through the display allowing visitors to see close at hand some of the most important local plants that would be difficult or nearly impossible to see in the wild due to their inaccessibility or the danger associated with their habitat.

\section{GLASSHOUSES}

In support of the core collections and to provide facilities for tender plants, a $604 \mathrm{~m}^{2}$ Dutch Venlo glasshouse complex costing £303k and containing five different temperature zones was constructed. The Warm Temperate Zone is home to a landscaped display of Southern and Western Cape flora of South Africa, in particular fynbos, strandveld succulent, succulent little karoo and shrubby karoo biomes, (Low \& Rebelo, 1998). Central and South American succulent and cacti plants and, in future, island floras, particularly those from the Canary Islands, Madeira, Cape Verde, The Azores and Madagascar, will be displayed on the surrounding benching. Adjoining this is the Sub-tropical Zone where many epiphytic plants, such as orchids, bromeliads, ferns, begonias and peperomias are grown. In time, the central display will be further landscaped to display these epiphytic plants better, under which will be grown our collection of sub-tropical cycads and other primitive plants including the ancient Sarcandra chloranthoides (Fig. 12) and 

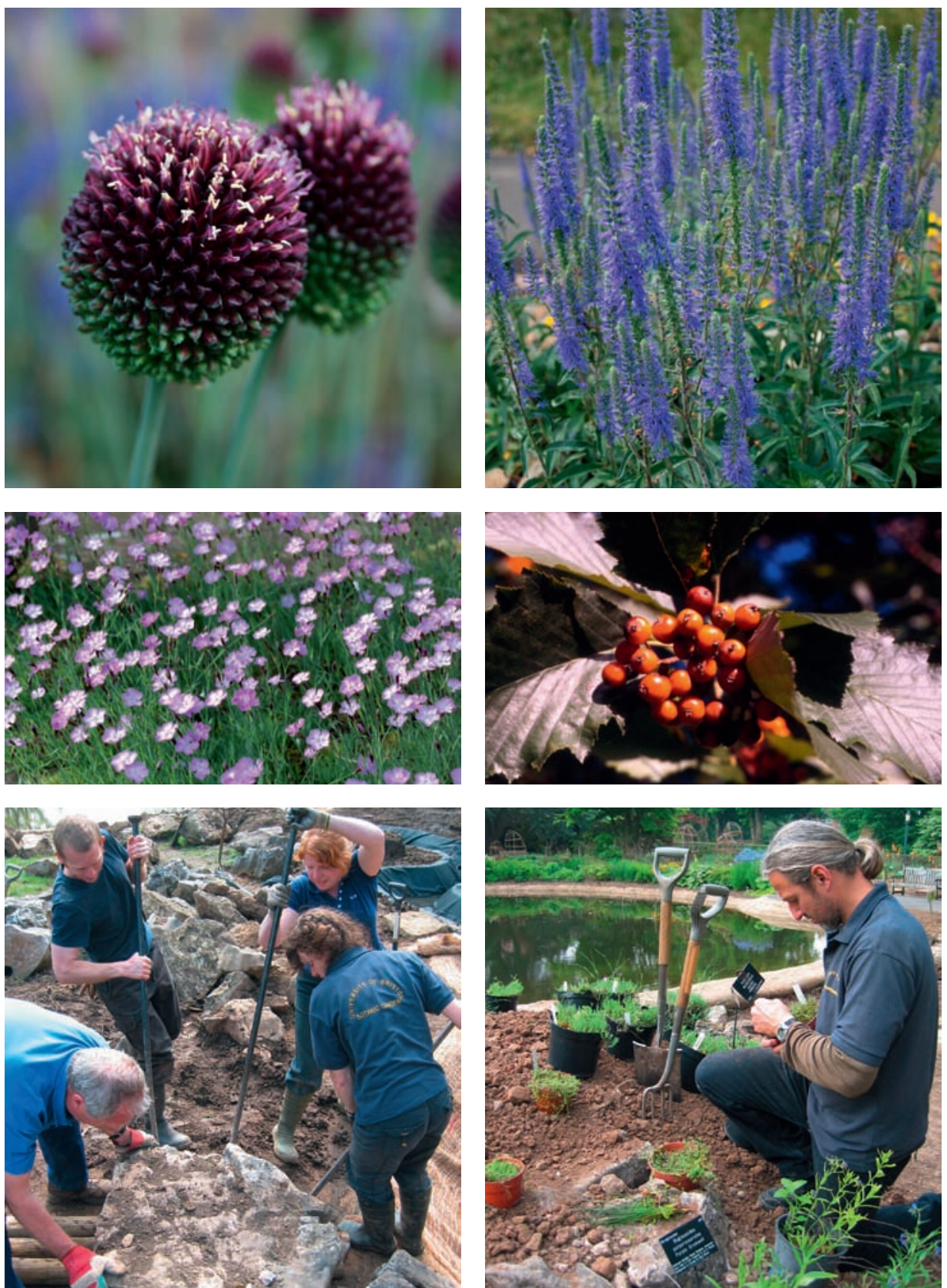

Fig. 11 Images from the Rare Local Flora and Threatened Native Plant Collection. Top left: The Avon Gorge Display of the endangered Allium sphaerocephalon. Top right: The locally rare Veronica spicata subsp. hybrida. Middle left: From the Mendip Hills, Somerset, the endangered Dianthus gratianopolitanus. Middle right: The Avon Gorge endemic Sorbus bristoliensis. Bottom left: UBBG staff building the Carboniferous Limestone Rock Garden entirely from recycled material. Bottom right: Planting up the Mendip Hills Display. Photos: Nicholas Wray. 


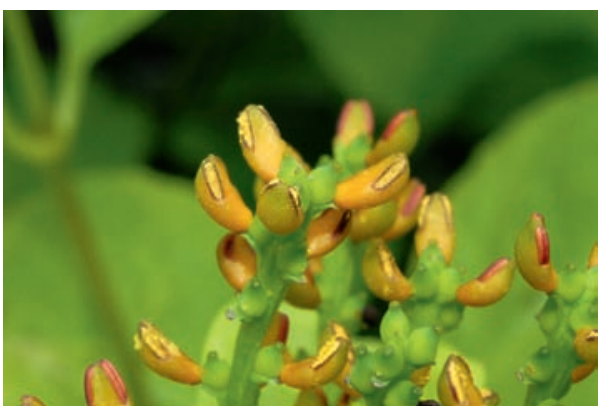

Fig. 12 Sarcandra chloranthoides is an ancient basal angiosperm in Chloranthaceae. It is restricted to India and Sri Lanka and produces numerous petalless flowers over a long period and is part of the Plant Evolution Collection. Photo: Dave Newbury.

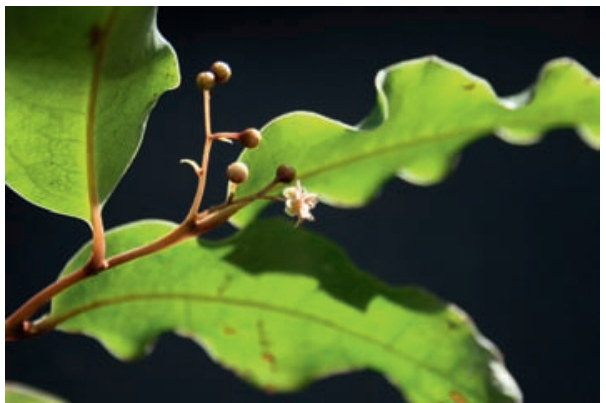

Fig. 13 The most primitive extant basal angiosperm, the monotypic species Amborella trichopoda is placed in the monotypic family Amborellaceae. Originating from New Caledonia it forms an important part of the Plant Evolution Collection. Photo: Nicholas Wray.

Amborella trichopoda (which is the most primitive extant flowering plant) (Fig. 13). Our plants were raised from seed collected in 2007 from the remote South Pacific island of New Caledonia by the Garden Director. They form part of a specialist collection of primitive flowering plants. Ferns and other lower plants are also grown in this zone which has a strong evolutionary theme.

The Tropical Zone is dominated by a raised central pool built of local Oolitic limestone (Cotswold Limestone). Plants of Victoria amazonica, V. cruziana and Euryale ferox are grown as annuals each year (Fig. 14). These are surrounded by a unique collection of sacred lotus, Nelumbo nucifera, which forms part of our Chinese Medicinal Plant Collection. The surrounding planting is devoted to tropical food and medicine and contains familiar plants such as Theobroma cacao, Saccharum officinarum, Cinnamomum zeylanicum, Vanilla planifolia, Musa 'Dwarf Cavendish', M. textilis, Bixa orellana and Catharanthus roseus. A series of paths made from the original Victorian cast iron floor grilles from the Bracken Hill garden provide an evaporation chamber to maintain the levels of humidity.

A Cool Zone currently used as a reserve area will in time be developed to display the

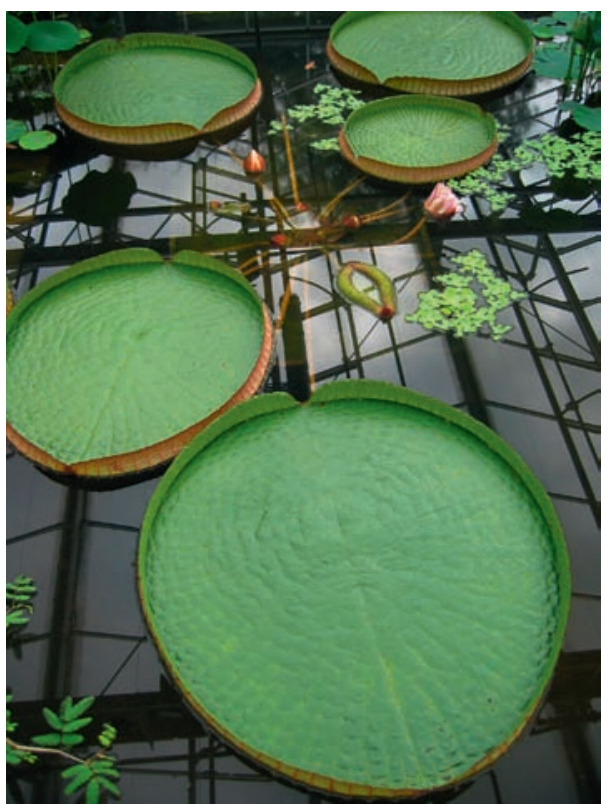

Fig. 14 Victoria cruziana with its beetle-pollinated flowers fills the raised tropical lily pool by late summer. It is one of a number of tropical aquatics forming part of the Plant Evolution Collection. Photo: Nicholas Wray. 
heath-land flora of Western Australia which will support the neighbouring Western Cape fynbos display. In addition, a display of carnivorous plants will be made showcasing the numerous adaptations for catching insects, and a display of Mediterranean climatic zone bulbous plants will be made illustrating their geographic distribution.

The Propagation Zone connects the display glasshouse zones to the potting shed. Here a wet mist unit, a propagation case and bench space provide facilities for the production of plants. A large potting shed designed to have adequate natural light for working and a neighbouring nursery space provide an area for the propagation of plants.

\section{INVESTMENT FOR THE UBBG}

To support the educational role of the UBBG a teaching room with state-of-the-art audio-visual facilities has been developed in the old stable buildings on the site. This is part of a $£ 225 \mathrm{k}$ investment by the Estates Office which has enabled the External Estates Department to invest in a new office, study room, machinery workshop, meeting room, and toilet facilities. All facilities together with the primary network of paths around the garden and glasshouses have been built to the latest DDA standards. This investment has been a welcome addition to the $£ 600 \mathrm{k}$ invested in the Garden by the University. This initial capital investment ensured that it has safely relocated and that the infrastructure was prioritised including the glasshouse at $£ 303 \mathrm{k}$ and potting shed at $£ 65 \mathrm{k}$. In addition, pathways, a water supply system, garden railings, services and landscaping were built in-house by both the Gardens and Grounds Maintenance teams. This group effort allowed the Garden to open to visitors in March 2006 only five short months from the completion of the move. Further annual investment of around $£ 25 \mathrm{k}$ from the External Estates Office and an annual investment of around £40k from the Friends of the Garden, plus generous gifts from the University Alumni of $£ 30 \mathrm{k}$, Stanley Smith Horticultural Trust $£ 7.5 \mathrm{k}$ and numerous other individual benefactors, have ensured that the Garden has had the finances to develop this far.

On the ground a small team of 5.5 staff dedicated to the UBBG have had tremendous support from 38 volunteer gardeners each week. With a mixture of ages, backgrounds and skills they have contributed a huge amount to the total effort, helping to achieve the collective goal of a completed garden. After four years in its new home three quarters of the garden has been planted. Over the next couple of years the primary planting will be completed.

The whole project has required careful planning. Planning applications and the construction of support buildings has been managed by the External Estates Manager Alan Stealey who project-managed the build.

\section{THE OPENING OF THE EVOLUTION COLLECTIONS}

The Evolutionary Collections were formally opened by the celebrated botanist and conservationist Professor David Bellamy OBE on 5 July 2008. After being welcomed 
by the Vice Chancellor Professor Eric Thomas, he spoke in his opening address of the value of botanic gardens and the bold investment that the University had made. He also said that it offers hope to the visitors who will learn about its work and be enthused by the plant displays. He thanked everyone who had been involved and asked everyone present to join him in shouting a collective "Wow!" before he cut the opening ribbon with a group of local school children (Fig. 15).

\section{MANAGEMENT AND STAFF STRUCTURE}

With the move to The Holmes a new management group was created for the UBBG. This is composed of Garden Director, Garden Curator and External Estates Manager. The group reports to a Botanic Garden Steering Group, chaired by a pro-Vice Chancellor and with relevant University stake holders and representation from the Friends of the Garden. The Management Group seek advice from the Curator's Advisory Group on matters relating to the plant collections and their interpretation and curation.

The Garden team comprises Glasshouse Co-ordinator, Outside Co-ordinator, two Botanical Horticulturists and a part-time Botanic Garden Administrator (Fig. 16). In addition, there are 38 volunteer gardeners each week, co-ordinated by the Glasshouse and Outside Co-ordinators, 30 volunteer guides with a Guide Co-ordinator, 40 welcome volunteers with a Welcome Lodge Co-ordinator and many other vital volunteer groups and individuals who support the Garden either directly or through the work of the Friends.

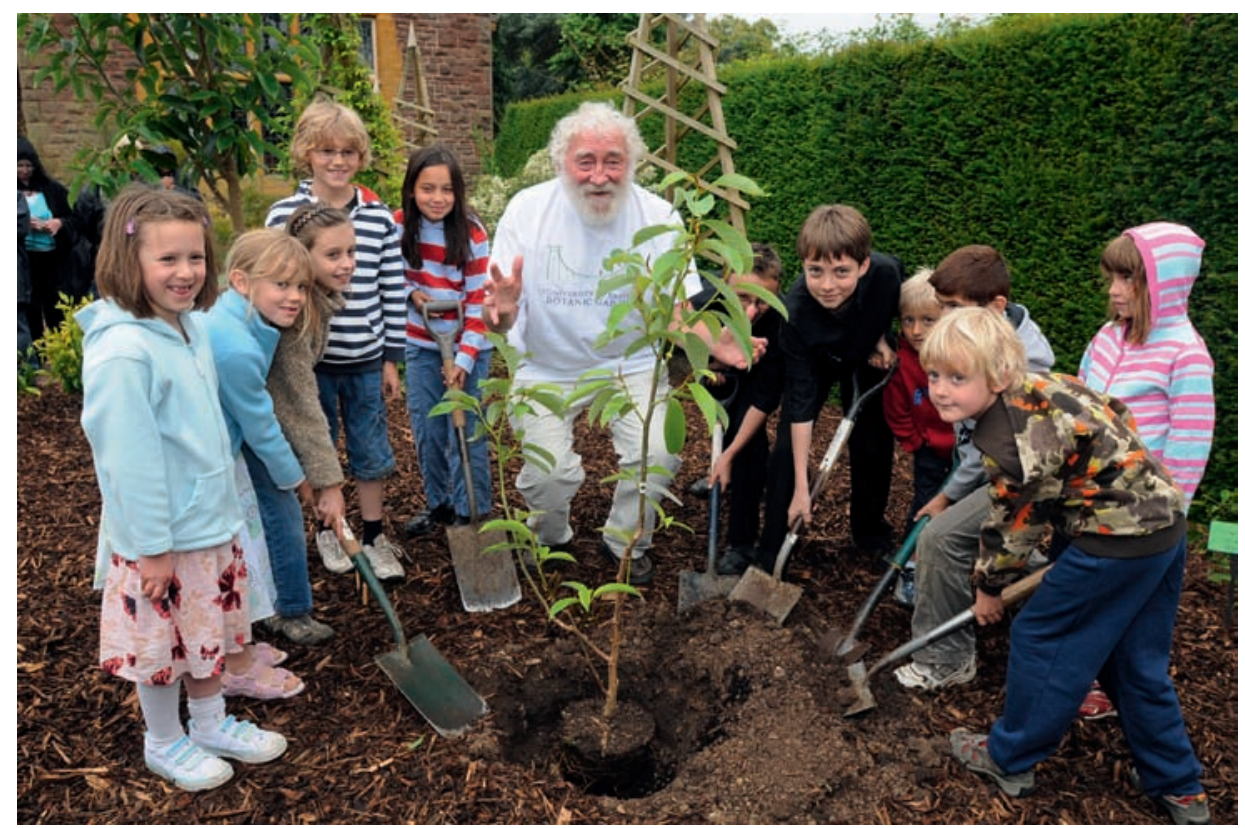

Fig. 15 Professor David Bellamy OBE formally opened the Evolution Collections. He planted a specimen of Magnolia doltsopa 'Silver Cloud' assisted by a group of local children. Photo: Martin Cainey. 


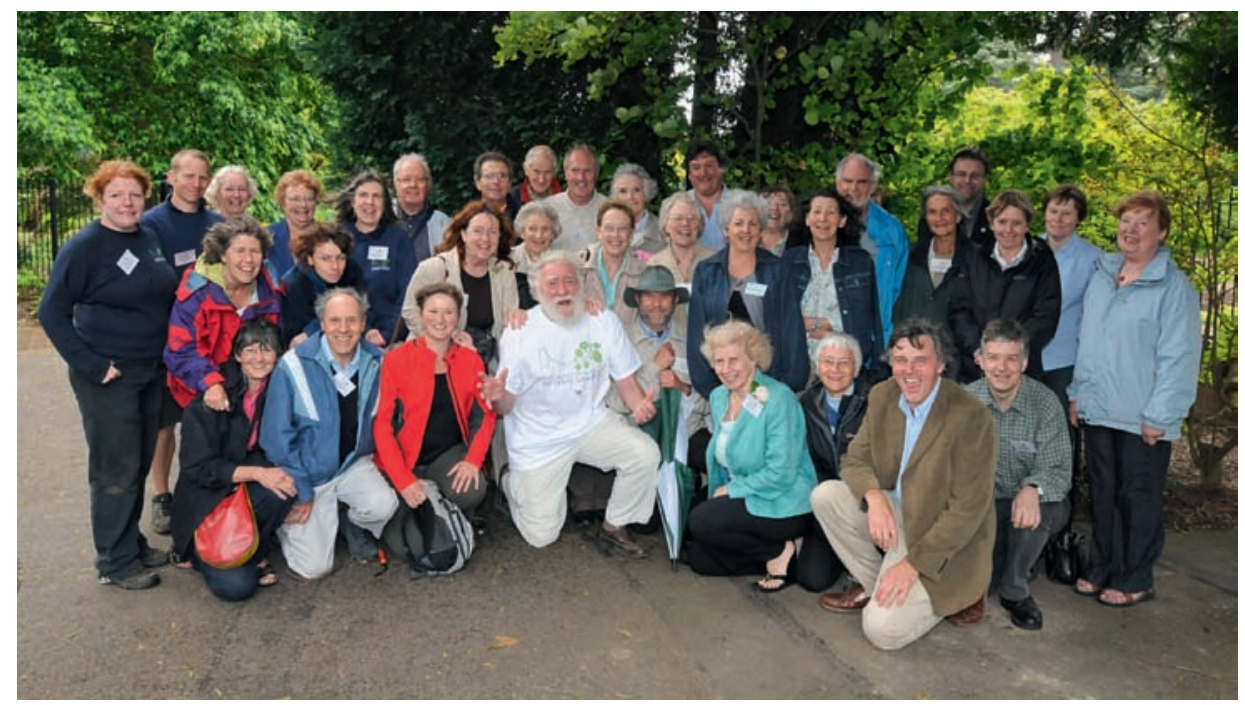

Fig. 16 The small team of five staff joined by the much larger team of volunteers and David Bellamy OBE at the opening celebrations. Photo: Martin Cainey.

\section{VISITOR AND EDUCATIONAL ACTIVITY}

Visitor numbers and schools' interest grows, and interest in adult education courses has also dramatically increased. The UBBG now offers both an evening and daytime Royal Horticultural Society (RHS) Level 2 Horticulture course and an evening RHS Level 3 Horticulture course. From autumn 2009 a year-long garden design course starts through a partnership with The Garden Design School. Other short courses including plant identification, ecology, botanical illustration, vegetable growing and medicinal plants continue to diversify and attract new audiences. Group tours prove to be a popular way of visiting the garden in the company of the volunteer guides (Fig. 17).

\section{THE FUTURE}

In the future the UBBG will take on an increasing role in the public understanding of science. A new electronic database provided by Iris Botanic Garden Database Systems linked to a label engraver will improve the quality of individual plant labels. Further work by third year biology students will provide new and innovative interpretation for students and visitors to learn about the plant collections, whilst themed events and exhibitions will attract new audiences. As the Garden continues to diversify and its plant displays mature it is hoped that more people will visit, particularly those taking garden tours. This is the most high-value way of seeing the Garden at its best and learning something new about the plants and how the collections are grown. With the natural world and our ability to use it wisely facing an uncertain future, we are confident that the 


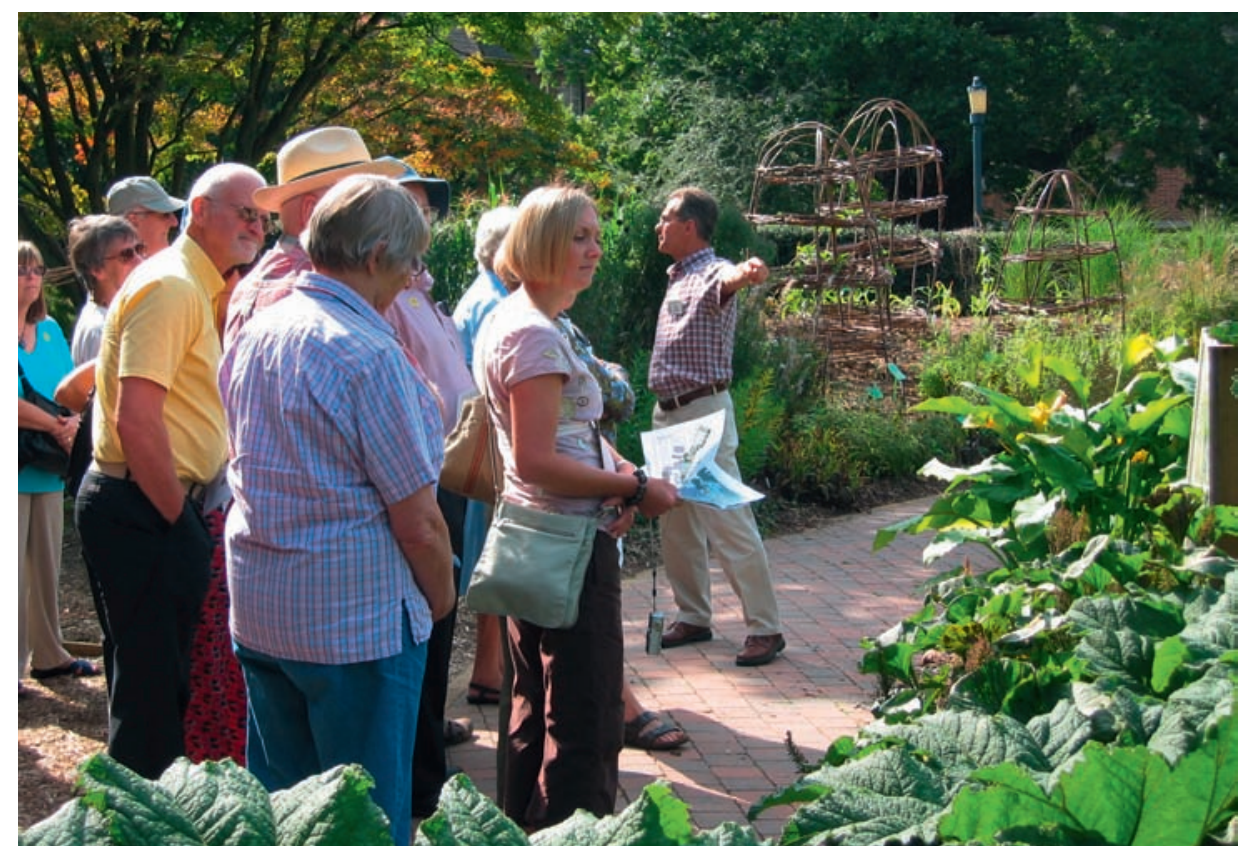

Fig. 17 A thirty-strong team of volunteer guides have a strategically important role in taking groups around the Garden. Photo: Nicholas Wray.

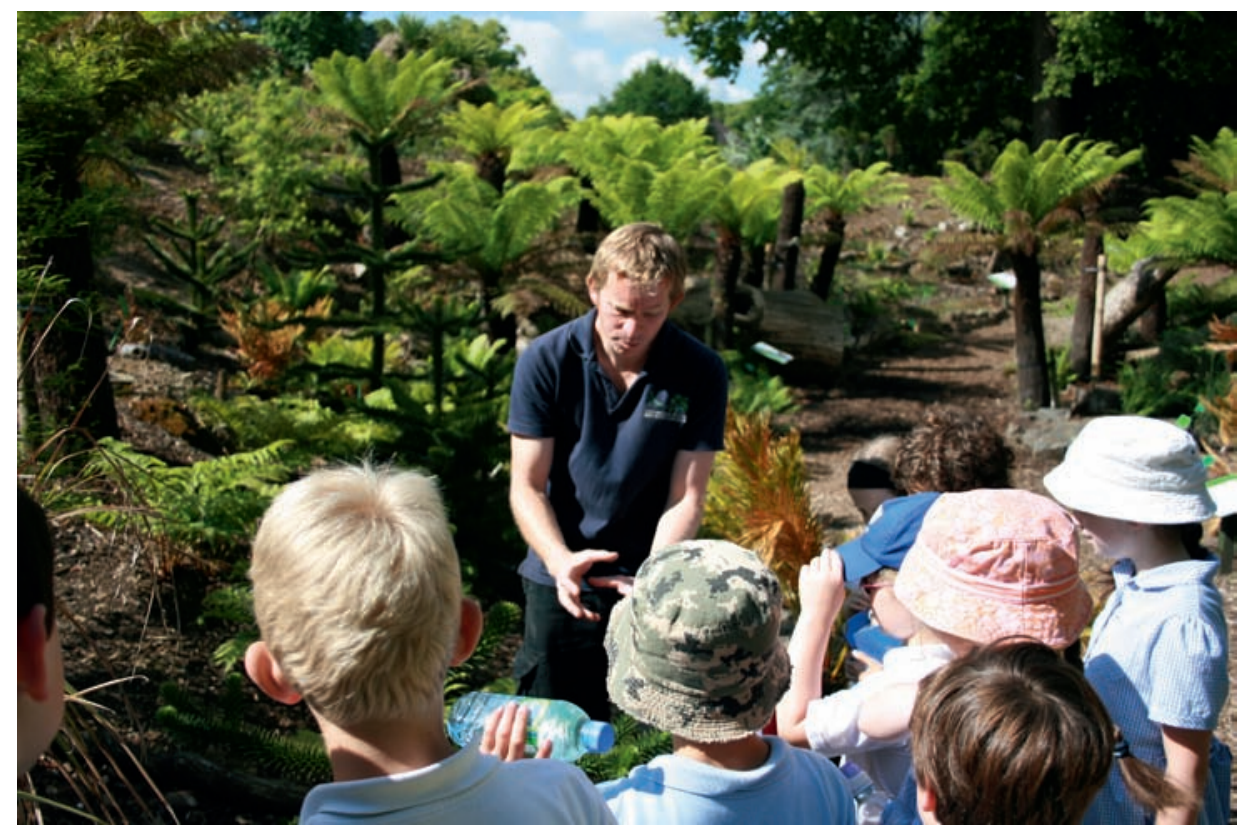

Fig. 18 The Evolution of Land Plants Display provides an inspirational setting for staff to enthuse school children of all ages about plants. Photo: Nicholas Wray. 
new University of Bristol Botanic Garden will enthuse people, be a centre for teaching and research and enable us to communicate the important messages about the wonderful world of plants.

The Garden is well placed to 'educate, communicate and conserve'.

\section{REFERENCES}

ABBOTT, S. (1979). 100 years of the 'The Holmes' 1879 -1979. S. Abbot, Bristol.

APG II (2003). An update of the Angiosperm Phylogeny Group classification for the orders and families of flowering plants: APG II. Botanical Journal of the Linnaean Society 141: 399-436.

CHENEY, J., NAVARRO, N. \& WYSE-JACKSON, P. (2000). Action Plan for Botanic Gardens in the European Union. National Botanic Garden of Belgium, Belgium.

DELANY, R. \& WINN, G. (2002). How Did This Garden Grow? The History of the Botanic Gardens of the University of Bristol. Friends of Bristol University Botanic Garden, Bristol.

Garden Route Botanic Garden (2006). Available at: www.gardenroutebotanicgarden.co.za (Accessed: July 2009)

HICKS, D. AIFA (29 August 2003). Archaeological Survey of the Holmes and Goldney House and Gardens. University of Bristol, Bristol.

JUDD, W.S., CAMPBELL, C.S., KELLOG, E.A., STEVENS, P.F., \& DONOGHUE, M.J. (2002). Plant Systematics a Phylogenetic Approach, Second Edition. Sinauer Associates Inc., Massachusetts.

LAWRENCE, D. \& HIGGINS, R. (1 September 2003). Ecological Report for The Holmes. Bristol.

LEADLAY, E. \& GREENE, J. (1998). Darwin Technical Manual for Botanic Gardens. Botanical Garden Conservation International (BGCI) London, U.K.

LEAR, M. (18 September 2003). Historic Landscape Survey of the Holmes. Oxford.

LOW, B. \& REBELO, T. (1998). Vegetation of South Africa, Lesotho and Swaziland. Department of the Environment Affairs \& Tourism, Pretoria.

SECRETARIAT OF THE CONVENTION ON BIOLOGICAL DIVERSITY (2002). Global Strategy for Plant Conservation Decision VI/9. Montreal, Canada.

WYSE-JACKSON, P.S. \& SUTHERLAND, L.A. (2000). International Agenda for Botanic Gardens in Conservation. Botanic Gardens International, Royal Botanic Garden Kew, UK. 